\title{
'Maurine Blue' Lisianthus [Eustoma grandiflorum (Raf.) Shinn.] - A University of Florida Cultivar ${ }^{1}$
}

Brent K. Harbaugh and John W. Scott ${ }^{2}$

Seedlings of commercial lisianthus cultivars form rosettes when grown at temperatures ranging from 25 to $28^{\circ} \mathrm{C}$ (Harbaugh et al., 1992; Ohkawa et al., 1991). Rosetted plants have a basal cluster of leaves and very short internodes typical of biennials. They do not bolt or flower for 3 to 6 months without being exposed to 3 to 4 weeks of temperatures at or below 15 to $18^{\circ} \mathrm{C}$ to reverse heat-induced rosetting (Ohkawa et al., 1994; Pergola, 1992). Semirosetted plants develop when seedlings are grown at a constant 22 to $25^{\circ} \mathrm{C}$ or at temperatures less than $22^{\circ} \mathrm{C}$ at night and above $28^{\circ} \mathrm{C}$ during the day. Although semirosetted plants have one or more side shoots that many elongate and flower, they flower unpredictably and are of poor quality as cut flowers or potted plants. Thus, commercial production of lisianthus for late spring or summer sales is limited by high temperatures in many areas of the United States and other countries. Fall plug production to produce flowering plants for early spring sales also is difficult due to rosetting of plugs caused by the interaction of high temperatures and short days (Harbaugh, 1995). 'Maurine Blue' is a heat-tolerant lisianthus developed at the Univ. of Florida's Gulf Coast Research and Education Center in Bradenton, FL. Seedlings have been produced at temperatures ranging from 28 to $31^{\circ} \mathrm{C}$ without rosetting.

\section{Origin}

'Maurine Blue' is the $\mathrm{F}_{1}$ hybrid resulting from crossing inbred lines GCREC-P76 and GCREC-9104 (Fig. 1). GCREC-P76 was an $\mathrm{F}_{4}$ selection of a cross between GCREC-8-57 and 'Yodel Pink'.

GCREC-8-57 was a self-pollinated plant $\left(\mathrm{S}_{1}\right)$ selected from 'Tosen' for its ability to flower in the summer $\left(35^{\circ} \mathrm{C}\right.$ day) and for its basal and lower branching characteristics. The 'Yodel Pink' plant was a selection that flowered after seedlings were exposed to $28^{\circ} \mathrm{C}$ temperatures in a growth chamber. In addition to its heat-tolerant characteristics, it was used because of its bell-shaped flowers and overlapping petals. Growing conditions used to select $\mathrm{F}_{1}$ to $\mathrm{F}_{4}$ GCREC-P76 seedlings for resistance to heat-induced rosetting were 1) production during summer months under greenhouse conditions at $\geq 35^{\circ} \mathrm{C}$ day in the $\mathrm{F}_{1}$; 2) exposure of 3- to 4-week-old seedlings to $28^{\circ} \mathrm{C}$ for 4 weeks in the $\mathrm{F}_{2}$ and $\mathrm{F}_{3}$; and 3 ) exposure of 17 -day-old seedlings to $31^{\circ} \mathrm{C}$ for 5 weeks in the $\mathrm{F}_{4}$. GCREC-9-104 was identified after 5 generations of self-pollination $\left(\mathrm{S}_{5}\right)$ from 'Blue Poppy'. Growing conditions used to select $S_{1}$ to $S_{5}$ generations for heat tolerance were 1) production of plants under summer greenhouse conditions in the $S_{1}$ and $S_{2} ; 2$ ) exposure

1. This is document ENH960, a publication of the Environmental Horticultural Sciences Department, Florida Cooperative Extension Service, Institute of Food and Agricultural Sciences, University of Florida. Publication date: July 2003. Please visit the EDIS Website at http://edis.ifas.ufl.edu.

2. Brent K. Harbaugh, professor, Gulf Coast Research and Education Center, Bradenton; John W. Scott, professor, Gulf Coast Research and Education Center, Bradenton, Cooperative Extension Service, Institute of Food and Agricultural Science, University of Florida, Gainesville, FL 32611. 
of seedlings to $28^{\circ} \mathrm{C}$ for 4 weeks in the $\mathrm{S}_{3}$ and $\mathrm{S}_{4}$; and 3) exposure of seedlings to $31^{\circ} \mathrm{C}$ for 5 weeks in the $\mathrm{S}_{5}$.

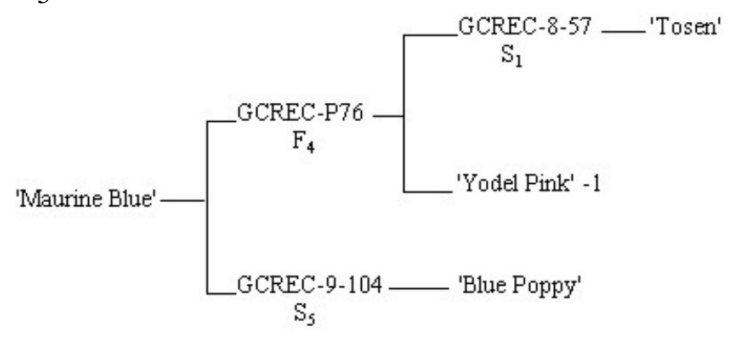

Figure 1. Pedigree for 'Maurine Blue' lisianthus.

\section{Description}

'Maurine Blue' tolerated greenhouse production temperatures year-round in Bradenton in 1994 with $0 \%$ to $6 \%$ rosetting (Table 1 ) even though day maximum summer and fall readings reached $35^{\circ} \mathrm{C}$ and night temperatures were rarely below $22^{\circ} \mathrm{C}$ $\left(18^{\circ} \mathrm{C}\right.$ minimum). During this evaluation, 'Maurine Blue' plants ranged from 38 to $58 \mathrm{~cm}$ in height (depending on planting date) and were 4 to $21 \mathrm{~cm}$ shorter than 'Flamenco Blue' and 'Yodel White'. 'Maurine Blue' flowered 87 and 120 days following sowing on 13 June and 13 Dec., respectively. 'Maurine Blue' can be considered an early flowering cultivar since it flowered earlier than typical commercial cultivars, such as 'Flamenco Blue' or 'Yodel White'.

When seeds of 'Maurine Blue', 'Blue Lisa', and 'Heidi Deep Blue' were planted on 5 Jan. at Bradenton and 17-day-old seedlings were grown at a constant $31^{\circ} \mathrm{C}$ for 5 weeks, no 'Maurine Blue' plants rosetted. However, all 'Blue Lisa' and 'Heidi Deep Blue' plants were semirosetted or rosetted (Table 2). 'Maurine Blue' plants were intermediate in height when compared to 'Blue Lisa' (a dwarf cultivar) and 'Heidi Deep Blue' (for cut flowers). There were more basal breaks (lateral stems forming from the first four to five leaf pairs before bolting) and lower breaks (lateral stems forming on the central flowering stem before the first flower bud) on 'Maurine Blue' plants compared to 'Heidi Deep Blue' or 'Blue Lisa'. 'Maurine Blue' had $40 \pm 6$ open flowers and buds 1 week after the first flower opened.

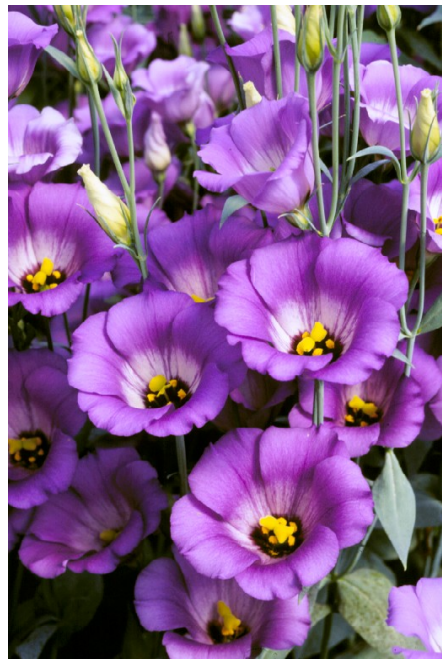

Figure 2. An array of 'Maurine Blue' lisianthus. Credits: Harbaugh

'Maurine Blue' flowers acropetally with a "tier-type" display of some cut flowers that concentrates most of the flowers on top of the plant. Flowers are bell shaped when open with a petal length of $5.5 \pm 0.1 \mathrm{~cm}$. When flowers first open, petals are violet-blue [Royal Horticultural Society (RHS) violet-blue group 89C; RHS, 1966] on the adaxial petal surface, diffusing to a variegated $1.8 \pm$ $0.2-\mathrm{cm}$ white band (RHS white group 155C) at the base of the petals. As flowers mature, petal color darkens to violet (RHS violet group 86A) and the white band fades or completely disappears. The abaxial petal surface is a lighter violet (RHS violet group 86B). The center of the flowers (i.e., base of the petals surrounding the ovary) is a dark purple (RHS purple group 79A).

\section{Characteristics and Use}

'Maurine Blue' ranged in height from 51 to 67 cm during 1994 and 1995 production trials in Bradenton and is intermediate in plant height when compared to commercial dwarf and cut flower cultivars. To our knowledge, it is the first heat-tolerant lisianthus cultivar of this height. 'Florida Blue', a semi-dwarf, heat-tolerant lisianthus cultivar, was released from our lisianthus breeding program in July 1995 (Harbaugh et al., 1996).

Growth retardants are necessary for production of 'Maurine Blue' in pots 12 to $15 \mathrm{~cm}$ in diameter. Plant height was $50 \pm 2.5 \mathrm{~cm}$ following foliar applications of butanedioic acid mono 
(2,2-dimethyllhydrazide) (daminozide) at $500 \mathrm{mg} \cdot \mathrm{L}^{-1}$ 3 weeks later. These plants were produced in 11.5 -cm square pots $(0.65-\mathrm{L})$ provided with capillary mat irrigation. Average plant height was $40 \pm 2 \mathrm{~cm}$ for 'Maurine Blue' plants treated with (2RS,3RS)-1-(4-cholorphenyl)-4,4-dimethyl-2-)1,2, 4-triazol-yl)penten3-ol (paclobutrazol) at $0.25 \mathrm{mg}$ a.i./pot applied as a soil drench when plants were to 7 cm tall.

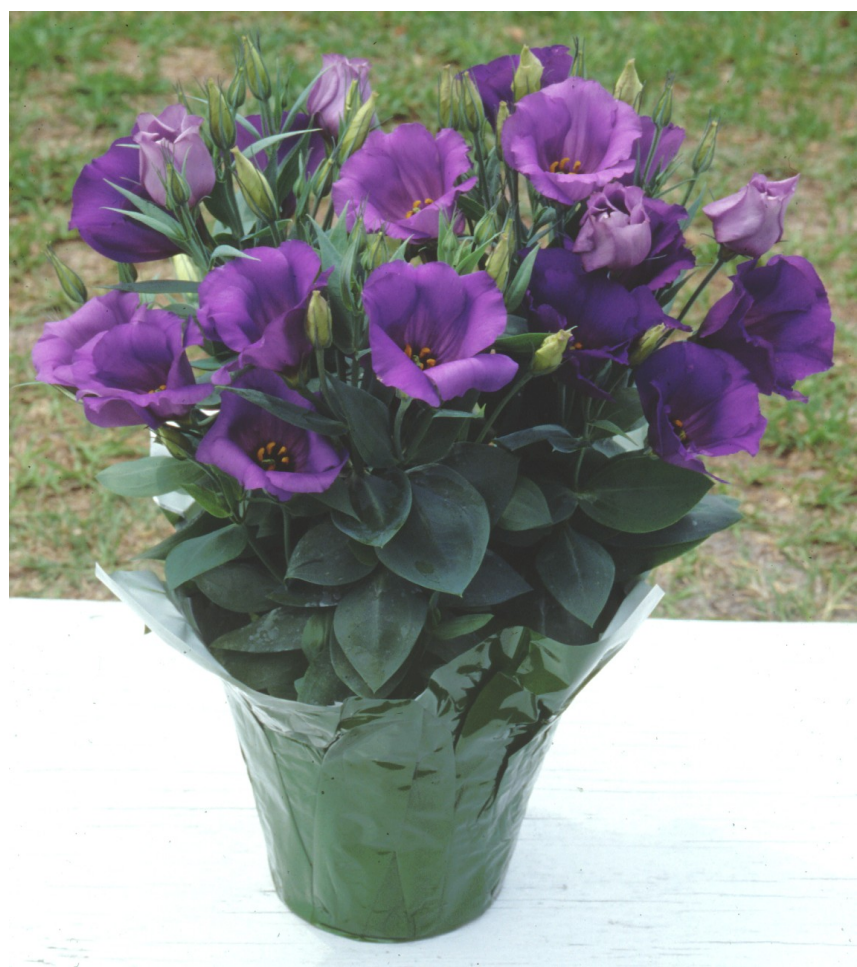

Figure 3. 'Maurine Blue' lisianthus.

While 'Maurine Blue' has more basal and lower branches than many commercial cultivars now forced in pots, three to four plugs per 12- to 15 -cm-diameter pot are suggested for optimal marketing display. Although this cultivar is intended to be used as a tall bedding plant or flowering potted plant, 'Maurine Blue' grown without growth retardants has a height suitable for the bouquet-cut flower market.

\section{Availability}

Plugs of 'Maurine Blue' will be offered for sale through Earl J. Small Growers, Pinellas Park, FL. Scientists interested in seed for research purposes can contact Dr. Harbaugh.

\section{Literature Cited}

Harbaugh, B.K. 1995. Flowering of Eustoma grandiflorum (Raf.) Shinn. Cultivars influenced by photoperiod and temperature. HortScience 30:1375-1377.

Harbaugh, B.K., M.S. Roh, R.H. Lawson, and B. Pemberton. 1992. Rosetting of lisianthus cultivars exposed to high temperatures. HortScience 27:885-887.

Harbaugh, B.K., J.W. Scott, and D.B. Rubino. 1996. 'Florida Blue' Semi-Dwarf Lisianthus [Eustoma grandiflorum (Raf.) Shinn.]. HortScience 31:1057-1058.

Ohkawa, K., A. Kano, K. Kanematsu, and M. Korenaga. 1991. Effects of Air Temperature and Time on Rosette Formation in Seedlings of Eustoma grandiflorum (Raf.) Shinn. Scientia Hort. 48:171-176.

Ohkawa, K., T. Yoshizumi, M. Korenaga, and K. Kanematsu. 1994. Reversal of Heat-induced Rosetting in Eustoma grandiflorum with Low Temperatures. HortScience 29:165-166.

Pergola, G. 1992. The Need for Vernalization in Eustoma russellianum. Scientia Hort. 51:123-127.

Royal Horticultural Society. 1966. Royal Horticultural Society Colour Chart. Royal Hort. Soc., London. 
Table 1. Response of lisianthus cultivars grown under greenhouse conditions in Bradenton, FL (lat. 27.5 $\mathrm{N}$ ), with four planting dates from 13 Dec. 1993 to 12 Sept. 1994.

\begin{tabular}{|c|c|c|c|c|c|c|c|c|c|}
\hline \multirow[b]{3}{*}{ Cultivar } & \multicolumn{9}{|c|}{ Days sown } \\
\hline & \multicolumn{3}{|c|}{14 Mar. } & \multicolumn{3}{|c|}{13 June } & \multicolumn{3}{|c|}{12 Sept. } \\
\hline & $\begin{array}{c}\text { Rosette }^{z} \\
(\%)\end{array}$ & $\begin{array}{l}\text { Plant }^{y} \\
\text { ht }(\mathrm{cm})\end{array}$ & $\begin{array}{l}\text { Days to } \\
\text { flower }^{y}\end{array}$ & $\begin{array}{c}\text { Rosette }^{z} \\
(\%)\end{array}$ & $\begin{array}{l}\text { Plant }^{y} \\
\text { ht }(\mathrm{cm})\end{array}$ & $\begin{array}{l}\text { Days to } \\
\text { flower }^{y}\end{array}$ & $\begin{array}{c}\text { Rosette }^{z} \\
(\%)\end{array}$ & $\begin{array}{l}\text { Plant }^{y} \\
\text { ht (cm) }\end{array}$ & $\begin{array}{l}\text { Days to } \\
\text { flower }\end{array}$ \\
\hline $\begin{array}{l}\text { Maurine } \\
\text { Blue }\end{array}$ & 0 & 38 & 89 & 6 & 57 & 87 & 0 & 58 & 112 \\
\hline $\begin{array}{l}\text { Flamenco } \\
\text { Blue }\end{array}$ & 62 & 43 & 102 & 47 & 61 & 105 & 33 & 79 & 130 \\
\hline $\begin{array}{l}\text { Yodel } \\
\text { White }\end{array}$ & 53 & 47 & 95 & 75 & 66 & 107 & 38 & 71 & 123 \\
\hline LSD 0.05 & & 5 & 2 & & 6 & 5 & & 9 & 8 \\
\hline $\begin{array}{l}{ }^{\mathrm{z}} \text { Percentag } \\
{ }^{\mathrm{y}} \text { Data of } \mathrm{pl} \\
\text { replications }\end{array}$ & $\begin{array}{l}f \text { rosette or } \\
\text { height and } \\
\text { single-plan }\end{array}$ & $\begin{array}{l}\text { nirosett } \\
\text { /s to flo } \\
\text { perimer }\end{array}$ & $\begin{array}{l}\text { lants, } n= \\
r \text { were fo } \\
\text { I units ar }\end{array}$ & in a & $\begin{array}{l}\text { nts. } \\
\text { izec }\end{array}$ & $\begin{array}{l}\text { es rep } \\
\text { olete-- }\end{array}$ & $\begin{array}{l}\text { the me } \\
\text { lesign. }\end{array}$ & of eight & \\
\hline
\end{tabular}

Table 2. Growth and flowering characteristics of lisianthus cultivars grown in $11.5-\mathrm{cm}$ square pots $(0.65-\mathrm{L})$ with capillary mat irrigation after exposure of seedlings to control or high temperatures ${ }^{2}$.

\begin{tabular}{|c|c|c|c|c|c|c|}
\hline \multirow[b]{2}{*}{ Cultivar } & \multicolumn{2}{|c|}{ Rosette $(\%)^{y}$} & \multirow[b]{2}{*}{$\begin{array}{r}\text { Plant ht } \\
(\mathrm{cm})^{\mathrm{x}}\end{array}$} & \multicolumn{2}{|c|}{ Breaks $^{x}$} & \multirow[b]{2}{*}{$\begin{array}{l}\text { Flowers } \\
\text { and buds }\end{array}$} \\
\hline & Control & $31 \mathrm{C}$ & & Basal & Lower & \\
\hline Maurine Blue & 0 & 0 & 67 & 3.5 & 4.5 & 40 \\
\hline Heidi Deep Blue & 0 & 100 & 81 & 0.2 & 2.9 & 32 \\
\hline Blue Lisa & 12 & 100 & 34 & 1.6 & 2.8 & 44 \\
\hline LSD 0.05 & & & 6 & 1.1 & 0.8 & 12 \\
\hline \multicolumn{7}{|c|}{$\begin{array}{l}{ }^{z} \text { Seedlings were grown in a greenhouse with a high of } 28 \text { to } 33^{\circ} \mathrm{C} \text { day and a low of } 13 \text { to } 15^{\circ} \mathrm{C} \text { night } \\
\text { (control), or } 17 \text {-day-old seedlings were exposed to } 31^{\circ} \mathrm{C} \text { for } 5 \text { weeks in a growth chamber and then } \\
\text { flowered in the greenhouse. } \\
{ }^{y} \text { Percentage of rosette or semirosette plants, } \mathrm{n}=25 \text {. } \\
{ }^{x} \text { Vegetative and flowering characteristics were for non-rosetted control plants. Values represent the } \\
\text { means of eight replications of single-plant experimental units arranged in a randomized complete-block } \\
\text { design. }\end{array}$} \\
\hline
\end{tabular}

